\title{
INOVASI ORGANISASI DAN KINERJA ORGANISASI : STUDI KASUS PADA PUSAT KAJIAN DAN PENDIDIKAN DAN PELATIHAN APARATUR III LEMBAGA ADMINISTRASI NEGARA ${ }^{1}$
}

\author{
ORGANIZATIONAL INNOVATION AND ORGANIZATIONAL \\ PERFORMANCE : CASE STUDY AT CENTER OF STUDY AND \\ EDUCATION AND TRAINING APPARATUS III NATIONAL \\ INSTITUTE PUBLIC ADMINISTRATION ${ }^{1}$
}

\author{
Dewi Sartika \\ Pusat Kajian dan Pendidikan dan Pelatihan Aparatur III LAN \\ Jalan HM Ardans SH (Ring Road III) Samarinda \\ E-mail : naurah10@yahoo.com
}

\begin{abstract}
This study describes and analyzes about influence of organizational innovation to the performance of the organization, a case study on the public authorities and the Center for the Study of Education and Training Aparatus III National Institute Public Administration Samarinda. In the previous study Muhammad Abdiaziz Sidow and Ali Yassin Sheikh Ali in 2014 has been researching the three dimensions of organizational innovation that administrative innovaton, technological innovation and strategies innovation, and the effect of its application to the performance of the organization. The research instrument was tested using Cronbach's alpha to test the reliability and consistency of the answer, while the descriptive is used to describe the characteristics of the respondents, and correlation analysis (regression) to examine the relationship between variables and hypotheses. By using cross sectional, data collection was conducted against 41 employees PKP2A III LAN in Samarinda, East Kalimantan province. Data collection was conducted in November 2014 and were analyzed using SPSS version 21. The results showed that technological innovation has the most important influence on organizational performance $(\beta=0.348, \alpha=0.863)$, followed by administrative innovation $(\beta=0.326, \alpha=$ $0.879)$, then innovation strategy $(\beta=0.318, \alpha=0.834)$. Therefore, a need for such an organization to believe that these factors need to be increased in order to improve organizational performance in the future.
\end{abstract}

Key Words : Administration innovation, technology innovation, strategy innovation, organizational performance

\footnotetext{
1 Naskah di terima pada 13 Januari 2015, revisi pertama pada 20 Maret 2015, disetujui pada 27 Juli 2015
} 


\begin{abstract}
Abstrak
Penelitian ini menggambarkan dan menganalisis pengaruh inovasi organisasi terhadap kinerja organisasi, mengambil studi kasus pada instansi pemerintahan yakni Pusat Kajian dan Pendidikan dan Pelatihan Aparatur III Lembaga Administrasi Negara (PKP2A III LAN) Samarinda. Pada penelitian sebelumnya Muhammad Abdiaziz Sidow dan Ali Yasin Sheikh Ali tahun 2014 telah meneliti tiga dimensi inovasi organisasi yaitu inovasi administrasi, inovasi teknologi dan inovasi strategi dan pengaruh penerapannya terhadap kinerja organisasi. Instrumen penelitian diuji dengan menggunakan Cronbach Alpha untuk menguji reliabilitas dan konsistensi jawaban, sedangkan analisis deskriptif digunakan untuk menjelaskan karakteristik responden, dan analisis korelasi (regresi) untuk menguji hubungan antara variabel dan hipotesis. Dengan menggunakan pendekatan cross sectional, pengumpulan data dilakukan terhadap 41 pegawai PKP2A III LAN Samarinda. Pengumpulan data dilakukan pada bulan November 2014 dan dianalisis menggunakan SPSS versi 21. Hasil penelitian menunjukkan bahwa inovasi tekhnologi mempunyai pengaruh yang paling penting terhadap kinerja organisasi $(\beta=0.348, \alpha=0.863)$, diikuti inovasi administrasi $(\beta=0.326, \alpha=0.879)$ kemudian inovasi strategi $(\beta=0.318, \alpha=$ 0.834 ). Karenanya, menjadi kebutuhan bagi organisasi tersebut untuk meyakini bahwa faktor faktor ini perlu ditingkatkan dalam rangka meningkatkan kinerja organisasi di masa yang akan datang.
\end{abstract}

Kata Kunci : Inovasi administrasi, inovasi teknologi, inovasi strategi, kinerja organisasi

\section{A. PENDAHULUAN}

Selama beberapa tahun terakhir, banyak organisasi yang berorientasi profit dan non-profit, baik swasta maupun pemerintah telah mengalami perubahan secara cepat, besar dan menyeluruh di berbagai aspek. Perubahan tersebut merupakan sebuah keniscayaan bagi setiap organisasi yang ingin tetap eksis dalam menghadapi tantangan zaman, sehingga setiap organisasi seyogyanya dapat berfokus untuk mengembangkan diri dan elemen di dalamnya untuk dapat beradaptasi dengan perubahan lingkungan yang setiap saat berkembang dan berubah dari karakteristik yang berbeda dari biasanya. Dengan kemampuan tersebut, organisasi tentunya dapat mencapai efektifitas, efisiensi dan menghasilkan kinerja yang tinggi dalam mencapai tujuan masingmasing.

Kondisi lingkungan eksternal dengan tingkat ketidakpastian yang tinggi, serta lingkungan yang semakin dinamis dan kompleks menjadi faktor pemicu terbesar pada banyak organisasi untuk melakukan inovasi. Teori Kontinjensi Lingkungan mengatakan bahwa : "Organisasiorganisasi yang berhasil adalah mereka yang dapat menyesuaikan struktur internal dengan karakteristikkarakteristik lingkungan (dinamis atau stabil).

Kecenderungan meningkatnya praktik-praktik inovasi pada organisasi dewasa ini dan di masa mendatang, sebagian besar karena perubahan 
Inovasi Organisasi Dan Kinerja Organisasi :

Studi Kasus Pada Pusat Kajian Dan Pendidikan Dan

Pelatihan Aparatur III Lembaga Administrasi Negara

Dewi Sartika

kondisi lingkungan eksternal, perubahan lingkungan persaingan, dan sebagainya. Inovasi menciptakan keunggulan bersaing. "Prospector is an organization that values being "first" with new products, market, and technologies even though not all efforts prove to profitable. It responds rapidly to early concerning areas of opportunity"(Fontana:2011,64).

Hasil survey Boston Consulting Group dalam Measuring Innovation 2008 : A BCG Senior Management Survey menemukan bahwa kebanyakan perusahaan $(79 \%$ responden $)$ menggunakan pengukuran untuk mengevaluasi komponen inovasi sisi ouput (innovation outputs), 70\% sisi input (innovation inputs), dan hanya $61 \%$ sisi proses (innovation process) atau sisi pengembangan ide atau sumber daya menjadi output." (Fontana : 2011, 103). Hasil survey sejenis terkait inovasi adalah Global Innovation 1000 yang memprofilkan tiga strategi innovator yaitu need seeker, market reader, dan technology drivers. Dua tipe pertama merupakan tipikal innovator penyesuai sedangkan tipe terakhir merupakan tipikal innovator pendaya tarik yang merupakan strategi inovasi yang lebih berisiko.

Contoh organisasi yang memanfaatkan inovasi dan rekayasa teknologi dalam melejitkan kinerja organisasinya adalah pemerintahan Kota Bantaeng, Sulawesi Selatan dibawah kepemimpinan Bupati Ir. Nurdin Abdullah, dimana Kota Bantaeng adalah kota pertama di Sulawesi Selatan yang memanfaatkan energi matahari untuk lampu pengatur lalu lintas kota. Selain itu, inovasi strateginya adalah menjadikan pembangunan infrastruktur sebagai prioritas karena dengan terbukanya akses jalan melancarkan pembangunan hingga ke pelosok dan tidak boleh ada jalan yang berlobang. Inovasi administratif dengan revitalisasi kapasitas SDM aparatur pemerintahan. Pada tahun pertama menjabat, semua kepala desa, lurah, camat, ketua LPM, dan Ketua BPD ke Surabaya untuk memperkuat sistem dan pola kebijakan, meski terjadi pergantian kepemimpinan.

Dimensi inovasi beririsan kuat dengan kinerja organisasi. Performa organisasi tidak hanya berbasis anggaran / finansial (input) tetapi juga mempertimbangkan aspel nonfinansial yang bersifat indirect dan intangible sebagai wujud nyata pencapaian akuntabilitas kinerja secara keseluruhan. Penilaian tidak hanya pada kelompok input, juga dilakukan analisis masukan keluaran (input output), analisis realisasi hasil (outcomes) dan manfaat (benefits) analisis dampak (impacts) baik positif maupun negatif, analisis keuangan maupun analisis kebijakan.

Sebagai organisasi pemerintah bervisi sebagai rujukan dalam pembaharuan administrasi negara di daerah, Pusat Kajian dan Pendidikan dan Pelatihan III Aparatur melakukan berbagai inovasi untuk meningkatkan performa organisasi. Salah satunya mendapatkan nominasi juara pertama dalam kategori Inovasi Teknologi yaitu implementasi electronic loog book bidang kajian berbasis intranet sebagai cikal bakal sistem pengukuran kinerja pegawai berbasis internet di Lembaga Administrasi Negara yang merupakan upaya penerapan Peraturan Pemerintah Nomor 46 Tahun 2011 
tentang Penilaian Prestasi Kerja Pegawai Negeri Sipil. Juara pertama dalam kategori inovasi teknologi juga didapatkan yaitu evaluasi program dan kegiatan melalui e-monev PKP2AIII.

Tidak hanya itu, inovasi penciptaan nilai diciptakan untuk mendongkrak kinerja melalui 5 Core Value organisasi, menumbuhkan budaya pembelajaran melalui forum Kelompok Budaya Kerja (KBK), penerapan manajemen arsip (Record Center) untuk menciptakan tertib administrasi, penerapan presensi elektronik (handkey dan fingerprint) untuk mengukur kehadiran pegawai, dan sebagainya. Penelitian ini bermaksud untuk melihat sejauh mana pengaruh inovasi yang telah diterapkan oleh instansi terhadap kinerja organisasi dari tiga aspek inovasi yaitu inovasi teknologi, inovasi administrasi dan inovasi strategi sehingga dapat menjadi bahan rujukan dalam membangun kinerja organisasi berkelanjutan.

\section{B. REVIEW LITERATUR}

\section{Inovasi Organisasi}

Untuk dapat menampilkan kinerja organisasi yang memuaskan atau tidak, diperlukan perubahan oganisasi yang bersifat strategis. Cara kerja organisasi yang masih menganut asas "seperti sedia kala" tidak lagi memadai di masa yang akan datang, di tengah persaingan yang bersifat lokal dan domestik bahkan regional dan global. Organisasi yang ingin meningkatkan produktivitas dan efektivitasnya, pada akhirnya menghadapi berbagai masalah yang timbul di masa depan, memerlukan cara berpikir dan bertindak yang inovatif. Inovasi dapat menyangkut penciptaan produk baru (baik dalam arti barang atau jasa), struktur baru, hubungan baru dan bahkan juga kultur baru. (Siagian, 2007; 258).

Ciri-ciri utama organisasi masa depan, menurut Alfin Toffler, futuris yang terkenal itu, ialah fleksibilitas, kreativitas dan inovasi. (Siagian, 2007 : 227). Salah satu tugas dan fungsi manajerial yang makin mendesak dan penting di masa mendatang adalah mengelola perubahan strategis yang berkarakteristik diantaranya integrasi strategi organisasi dengan strukturnya, teknologi yang digunakan serta sumber daya manusia di dalamnya. Berbagai faktor tersebut disesuaikan lagi dengan tuntutan lingkungan eksternal organisasi. Maka menjadi penting kiranya dalam transformasi organisasi tersebut yaitu pemahaman yang utuh tentang transformasi organisasi, kultur organisasi, matriks "strategi-kultur" dan manajemen perubahan strategis. Pengelolaan empat isu perubahan (inovasi) organisasi tersebut berikut pengembangan dan pelaksanaannya yang bersifat partisipatif menjadi penting kiranya untuk dibahas.

Organisasi berinovasi merupakan tuntutan dari transformasi organisasi yang tidak lagi semata pengembangan organisasi manakala suatu organisasi belum mampu menampilkan performa yang memuaskan, atau tidak mampu menyesuaikan perubahan lingkungan eksternal yang demikian kompetitif, dan skala organisasi masih kecil dan bertumbuh pesat. Berikut gambaran tipe perubahan keorganisasian, sebagaimana tabel beikut: 
Inovasi Organisasi Dan Kinerja Organisasi

Studi Kasus Pada Pusat Kajian Dan Pendidikan Dan

Pelatihan Aparatur III Lembaga Administrasi Negara

Dewi Sartika

Tabel 1.

Tipe-tipe perubahan keorganisasian

\begin{tabular}{|c|c|}
\hline $\begin{array}{l}\text { Perubahan strategis } \\
\text { - Postur perubahan } \\
\text { - Pendekatan berbalik arah } \\
\text { - Penarikan diri } \\
\text { - Stabilitas }\end{array}$ & $\begin{array}{l}\text { Perubahan struktural } \\
\text { - Reorganisasi fungsional; } \\
\text { - Mendatarkan hierarkhi } \\
\text { - Struktur tim } \\
\text { - Desentralisasi kekuasaan }\end{array}$ \\
\hline $\begin{array}{l}\text { Perubahan teknologis } \\
\text { - Otomasi proses } \\
\text { - Networking } \\
\text { - Memutakhirkan peranti keras } \\
\text { - Aplikasi baru peranti lunak atau } \\
\text { konversi }\end{array}$ & $\begin{array}{l}\text { Perubahan manusia } \\
\text { - Sikap atau isu-isu tentang komitmen } \\
\text { - Dampak-dampak kinerja atau perbaikan- } \\
\text { perbaikan } \\
\text { - Inisiatif-inisiatif sehubungan dengan } \\
\text { kualitas kehidupan kerja } \\
\text { - Redesain pekerjaan atau upaya-upaya } \\
\text { motivasi }\end{array}$ \\
\hline
\end{tabular}

Sumber : Lussier, 1997 : 248 dalam Winardi, 2010, 92

Hurley and Hult (1998) dalam Kusumo, (2006: 22) mendefinisikan inovasi sebagai sebuah mekanisme perusahaan untuk beradaptasi dalam lingkungan yang dinamis, oleh karena itu perusahaan dituntut untuk mampu menciptakan pemikiran-pemikiran baru, gagasan-gagasan baru dan menawarkan produk yang inovatif serta peningkatan pelayanan yang memuaskan pelanggan.

Dalam sisi lain produk inovasi menurut Galbraith, 1973; Schon, 1967 (dalam Lukas dan Ferrel, 2000: 240) didefinisikan sebagai proses dari penggunaan teknologi baru kealam suatu produk sehingga produk tersebut mempunyai nilai tambah. Inovasi dapat dilakukan pada barang, pelayanan, atau gagasan-gagasan yang diterima oleh seseorang sebagai sesuatu yang baru, sehingga mungkin saja suatu gagasan telah muncul di masa lampau, tetapi dapat dianggap inovatif bagi konsumen yang baru mengetahuinya.

Inovasi teknologi membantu perusahaan untuk membangun keunggulan kompetitif, layanan dan proses yang lebih efektif, bisnis yang baru, dan sebagainya. Technological innovation is not time barred and budgetary constraints and cost-benefit methods may to some extents hindered the application of its strategic management effectiveness. It is difficult to calculate and justify the dollar value of time spent in any $R \& D$ project that is directed towards improved technology innovation. As technology innovation can help the company to build competitive advantage through making more competitive products and services and more effective processes, or creating completely new business, both academic re-searchers and managers have been paying much attention to the explanation of innovation success. (Shengbin Hao, Bo Yu; iBusiness, 2011, 3, 366-371).

Pendapat yang sama yaitu Technology is the result of man's learned and acquired knowledge or his technical skills regarding how to do things well (Khalil dalam Dauda, 2000:1). Akuisisi teknologi, penggunaan dan pemeliharaan merupakan faktor penentu utama untuk bertahan hidup di semua organisasi. Di sisi lain, Quinn (dalam Dauda, 2000:2) berpendapat "that it is incumbent on any organisation to monitor 
technological changes, train and motivate employees to innovate, because technology covers every aspect of all organizations". Merupakan kewajiban setiap organisasi untuk memantau perubahan teknologi, melatih dan memotivasi karyawan untuk berinovasi karena teknologi meliputi semua aspek dari semua organisasi.

Drucker dalam Hutauruk (2010 : 3) menekankan bahwa secara spesifik, inovasi yang sistematis berarti memonitor tujuh sumber peluang inovasi. Empat sumber yang pertama terdapat di dalam organisasi, baik usaha maupun lembaga pelayanan masyarakat, atau di dalam organisasi.

Prediktor dan Faktor Perubahan

\begin{tabular}{|c|c|}
\hline $\begin{array}{l}\text { Prediktor } \\
\text { Perubahan }\end{array}$ & Faktor Perubahan \\
\hline Teknologi & $\begin{array}{l}\text { - Internet dan World Wide Web } \\
\text { - Teknologi informasi (Enterprise Resource Managemenet, ERM) } \\
\text { - Genetic Engineering } \\
\text { - Komputer-komputer dan robot-robot } \\
\text { - Teknik-teknik manajemen kualitas statistical } \\
\text { - Process re-engineering }\end{array}$ \\
\hline $\begin{array}{l}\text { Kondisi-kondisi } \\
\text { ekonomi }\end{array}$ & $\begin{array}{l}\text { - Resesi atau ekspansi } \\
\text { - } \text { Fluktuasi-fluktuasi suku bunga } \\
\text { - Tingkat tenaga kerja internasional } \\
\text { - Regulasi dan tindakan-tindakan peradilan }\end{array}$ \\
\hline $\begin{array}{l}\text { Kompetisi } \\
\text { global }\end{array}$ & $\begin{array}{l}\text { - Keberhasilan ekonomi Negara-negara di Asia } \\
\text { - Unifikasi Uni Eropa (dan timur/barat) } \\
\text { - Merger-merger dan konsolidasi-konsolidasi }\end{array}$ \\
\hline $\begin{array}{l}\text { Perubahan } \\
\text { sosial dan } \\
\text { demografik }\end{array}$ & $\begin{array}{l}\text { - Perhatian yang makin meningkat terhadap persoalan lingkungan } \\
\text { - Diversitas kultural yang makin meningkat } \\
\text { - Tingkat edukasi tenaga kerja yang meningkat } \\
\text { - Kesenjangan yang meningkat antara kelompok kerja dan orang } \\
\text { miskin }\end{array}$ \\
\hline $\begin{array}{l}\text { Tantangan- } \\
\text { tantangan } \\
\text { internal }\end{array}$ & $\begin{array}{l}\text { - Masalah perilaku : turn over yang tinggi, absentisme, pemogokan } \\
\text { - Problem proses : kebekuan komunikasi dan pengambilan keputusan } \\
\text { atau inovasi } \\
\text { - Pertentangan antara etika kerja dan etika sosial di banyak Negara } \\
\text { - Politik keorganisasian dan konflik keorganisasian yang destruktif }\end{array}$ \\
\hline
\end{tabular}

Selanjutnya tiga sumber yang kedua merupakan perubahan yang terjadi di luar organisasi. Inovasi secara berkesinambungan, diantaranya memperbaiki produk dan jasa untuk menghadapi permintaan konsumen yang selalu berubah, pelayanan publik yang dinamis, menghadapi iklim persaingan yang kompetitif. Teknologi yang digunakan kemudian disesuaikan dan diperbaharui dengan cara yang lebih baru dan lebih baik, untuk melaksanakan pengorganisasian dan manajemen. Berikut contoh-contoh aneka macam kekuatan dan contohcontoh perubahan dalam organisasi, sebagaimana tersaji dalam tabel berikut:

Tabel 2. 
Inovasi Organisasi Dan Kinerja Organisasi

Studi Kasus Pada Pusat Kajian Dan Pendidikan Dan

Pelatihan Aparatur III Lembaga Administrasi Negara

Dewi Sartika

Tabel 3.

Karakteristik Layanan

\begin{tabular}{|c|l|}
\hline Kategori & \multicolumn{1}{c|}{ Karakteristik } \\
\hline Windows dressing & $\begin{array}{l}\text { Tidak berbeda secara signifikan dengan layanan yang diberikan } \\
\text { perusahaan organisasi / perusahaan. }\end{array}$ \\
\hline Breadth of offering & $\begin{array}{l}\text { Terdapat rancangan yang berbeda dari isi layanan, tetapi } \\
\text { diantarkan dengan cara yang sama. }\end{array}$ \\
\hline Revolutionary & Sama sekali baru, baik dari isi maupun cara pelayanannya. \\
\hline Channel development & $\begin{array}{l}\text { Memberikan layanan yang s ama namun menggunakan saluran } \\
\text { yang berbeda. }\end{array}$ \\
\hline
\end{tabular}

Sumber : Wibisono : 2006, 113

Kaplan dan Norton menjadikan inovasi sebagai perwajahan baru organisasi untuk menandai kesiapan bersaing, sehingga keefektifan, efisiensi dan cepat dalam berinovasi bagi banyak organisasi atau perusahaan lebih menentukan ketimbang kemahiran (excellence) dalam operasi sehari-hari. (Wibisono : 2006, 110). Ada tidaknya inovasi dalam suatu organisasi dapat dilihat dari karakteristik layanan yang diberikan.

Schiemann (2011: 65) menjelaskan inovasi sebagai kemampuan mengembangkan dan melaksanakan ide-ide baru, kreatifitas yang mendorong ke arah jasa dan produk yang lebih baik, serta ketangkasan beradaptasi dengan lingkungan yang berubah atau lanskap yang kompetitif. Inovasi adalah bagian bentuk dari elemen terkompleks organisasi karena tidak tercakup dalam satu departemen karena inovasi dapat terjadi pada level organisasi, unit, proses, atau individu. Ragamnya definisi inovasi menyebabkan seringnya salah tafsir. Pengertian itu mengerucut pada makna "kreativitas" hingga "penciptaan sesuatu yang baru" dan ketangkasan organisasi pada tingkat terluas.

Jadi dari berbagai definisi diatas, penulis menyimpulkan bahwa inovasi organisasi merupakan cara dan perspektif baru untuk memberi nilai tambah bagi keluaran organisasi.

\section{Kinerja Organisasi}

Keberadaan suatu organisasi pada hakikatnya untuk mencapai tujuan. Tujuan itu pada akhirnya harus dideskripsikan dengan jelas sehingga menjadi tolok ukur keberhasilan atau kegagalan dalam proses pencapaian tujuan itu. Untuk mengawal pencapaian tujuan terseut maka menjadi tugas pemimpin organisasi, yang diwujudkan dalam suatu manajemen kinerja. Sedangkan kinerja (performance) itu sendiri merupakan gambaran tingkat pencapaian pelaksanaan suatu kegiatan /program / kebijakan dalam rangka mewujudkan sasaran, tujuan, misi dan visi organisasi yang tertuang dalam strategic planning suatu organisasi. Sedangkan pengukuran kinerja (performance measurement) merupakan proses penilaian kemajuan pekerjaan terhadap tujuan dan sasaran yang telah ditentukan sebelumnya termasuk informasi atas : efisiensi penggunaan 
Inovasi Organisasi Dan Kinerja Organisasi : Studi Kasus Pada Pusat Kajian Dan Pendidikan Dan Pelatihan Aparatur III Lembaga Administrasi Negara

sumber daya dalam menghasilkan barang dan jasa, kualitas barang dan jasa (seberapa baik barang dan jasa terserahkan ke pelanggan dan sampai pelanggan terpuaskan); hasil kegiatan dibandingkan dengan maksud yang diinginkan dan efektifitas tindakan dalam mencapai tujuan (Robertson dalam Mahsun, 2006, 25).

Whittaker dalam Mahsun (2006: 25) menjelaskan urgensi pengukuran kinerja sebagai alat manajemen untuk meningkatkan kualitas pengambilan keputusan dan akuntabilitas. Sehingga dapat disimpulkan kinerja merupakan alat manajemen organisasi dan pengukuran kinerja merupakan bagian dari sistem pengambilan keputusan dan akuntabilitas organisasi.

Jose Pottinger, Direktur SDM pada Cummins Engines Limited menjelaskan pada peneliti IPD (Insitute Personel and Development) bahwa manajemen kinerja akan memberi kejelasan harapan, kaitan antara sasaran individu dan sasaran organisasi, serta fokus perbaikan dengan menetapkan data yang diperlukan untuk melakukan perbaikan dan bentuk umpan baliknya. (Pottinger, 2003 : 198). Manajemen kinerja tidak semata dipandang sebagai dimensi yang memperbaiki kinerja organisasi akan tetapi bergerak dari proses yang mengendalikan menjadi proses yang memampukan sehingga dapat dikatakan menggerakkan daya kreatifitas dan inovasi pada SDM organisasi sama dengan menggerakkan pendongkrak kinerja organisasi, bukan semata formalitas mengisi formulir satu tahun sekali, atau pertemuan untuk meningkatkan angka kenaikan gaji atau tunjangan kinerja. Akan tetapi, manajemen kinerj adalah proses berkelanjutan terkait kinerja menyeluruh organisasi dan bagaimana tim atau organisasi berkontribusi pada pencapaian kinerja tersebut.

Terkait dengan inovasi, Burril dan Ledolter mengemukakan bahwa perbaikan kinerja organisasi atau perusahaan berarti pembentukan budaya perusahaan yang tajam dan tiap-tiap individu di dalam organisasi itu membutuhkan jaminan penuh akan dukungan manajemen puncak. (Wibisono : 2006, 110). Everyone starts with " $A$ " adalah inovasi strategi Benyamin Zander konduktor Boston Philharmonic Orchestra dalam mendongkrak prestasi muridnya, mengajar murid-murid baru dengan memberi nilai A pada awal semester. Ini sebagai bentuk menghargai secara nyata kemampuan, potensi tiap individu untuk memotivasi pembelajaran dan meninggikan keyakinan diri "self esteem" mereka dalam mempertahankan nilai " $\mathrm{A}$ ". Sekaligus membangun iklim keakraban dan kolaboratif dengan rekan dan dengan guru.

Pakar manajemen kinerja Bates, RA dan Holton E. F dalam Darto (2011 : 337) menjelaskan bahwa kinerja merupakan suatu konstruksi atau konsepsi yang multidimensional dimana pengukuran mengenai hal itu sangat bervariasi tergantung pada jenis dan faktor-faktor yang ada. Sepakat dengan argument di atas, manajemen kinerja merupakan proses manajemen yang menghasilkan outcome melalui perencanaan SDM, pengembangan, penilaian dan proses pemberian penghargaan sehingga tercapai target kinerja yang ditetapkan organisasi (LAN, 2009, 2010 dalam Darto, 2011).

Manajemen kinerja sebagai itu 
Inovasi Organisasi Dan Kinerja Organisasi

Studi Kasus Pada Pusat Kajian Dan Pendidikan Dan

Pelatihan Aparatur III Lembaga Administrasi Negara

Dewi Sartika

sendiri merupakan sarana untuk mendapatkan hasil yang lebih baik dari organisasi, tim dan individu dengan cara memahami dan mengelola kinerja dalam suatu kerangka tujuan, standard an persyaratan-persyaratan kompetensi terencana yang telah disepakati. Manajemen kinerja merupakan proses pemahaman bersama tentang apa yang harus dicapai, dan penciptaan suatu pendekatan terhadap pengelolaan dan pengembangan orang dengan suatu cara yang meningkatkan profitabilitas bahwa pendekatan tersebut dapat dicapai dalam waktu yang singkat dan berjangka waktu lebih lama. (Amstrong dalam Wibowo, $2006: 66$ ).

Organisasi pemerintah sebagai pure non profit organization memiliki karakteristik yang berbeda dengan organisasi bisnis. Dimensi kinerja organisasi tidak hanya berbasis anggaran / finansial (input) tetapi juga m e mpertimbangkan aspek nonfinansial yang bersifat indirect dan intangible sebagai wujud nyata pencapaian akuntabilitas kinerja secara keseluruhan. Penilaian tidak hanya pada kelompok input, juga dilakukan analisis masukan keluaran (input output) analisis realisasi hasil (outcomes) dan manfaat (benefits) analisis dampak (impacts) baik positif maupun negatif, analisis keuangan maupun analisis kebijakan. Formulasi sistemnya harus memuat secara komprehensif sehingga sistem kompensasi memiliki dasar obyektif.

\section{A.KERANGKA KONSEPTUAL DAN BANGUNAN HIPOTESIS \\ 1. Kerangka Konseptual}

Argumen konseptual dari penelitian sebelumnya adalah mengukur pengaruh inovasi organisasi dan kinerja perusahaan dalam Abdiaziz dan Ali (2014). Kurang lebih sama dengan riset yang dijalankan ini yang sama-sama menyelidiki hubungan antara inovasi organisasi dan kinerja organisasi. Riset ini menguji sejauh mana dampak dari elemen inovasi organisasi sebagai dari variabel independen yang terdiri dari tiga konstruk (teknikal, administratif, dan strategi inovasi) terhadap kinerja organisasi. dimana variabel inovasi tekhnologi (X1), inovasi administrasi (X2), inovasi strategi (X3) dan kinerja organisasi PKP2A II LAN (Y), (Gambar 1). dengan skema kerangka pikir sebagai berikut:

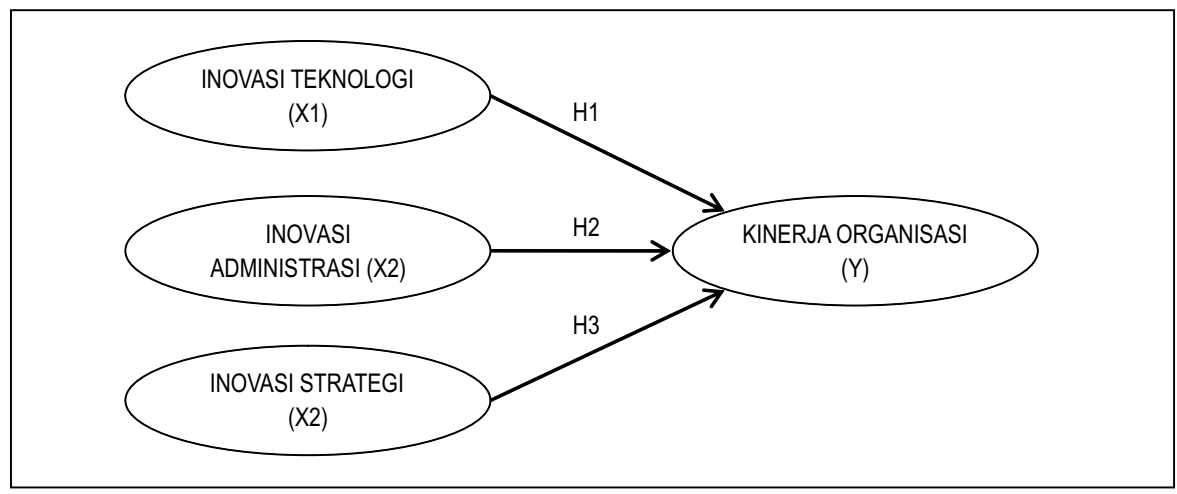

Gambar 1.

Kerangka Konsep Penelitian 
Organisasi (organization) secara formal itu sebagai entitas sosial yang diarahkan oleh tujuan dan dibangun secara sengaja (Daft : 2012, 9). Entitas sosial itu sendiri berarti terdiri atas dua atau lebih orang. Diarahkan oleh tujuan berarti dirancang untuk mencapai tujuan tertentu. Dibangun secara sengaja berarti bahwa ada pembagian tugasdan tanggung jawab pencapaian tugas tersebut dibebankan kepada para anggota organisasi. Definisi ini berlaku baik organisasi profit (semisal perusahaan swasta) atau nonprofit (semisal organisasi pemerintah). Dalam organisasi bisnis, Darmawan Wibisono $(2006 ; 117)$ mengungkapkan adanya keterkaitan antara inovasi dengan perspektif keluaran organisasi, dimana terdapat dua aspek yaitu aspek finansial dan non-finansial.

Dari definisi diatas, maka tanggung jawab manajer / pimpinan organisasi adalah mengordinasikan sumber daya yang ada secara efisien dan efektif guna mencapai tujuan organisasi. Efektifitas (effectiveness) organisasi berarti sejauh mana organisasi dapat mencapai tujuan yang ditetapkan, atau berhasil mencapai apapun yang dikerjakannya. Efisiensi (efficiency) organisasi adalah jumlah sumber daya yang digunakan untuk mencapai tujuan organisasional dalam jumlah keluaran tertentu. Faktor biaya (cost) harus diperhatikan tetapi pemangkasan biaya secara besarbesaran untuk meningkatkan efisiensi terkadang dapat mengganggu efektifitas organisasi. Tanggung jawab terbesar pimpinan organisasi adalah untuk mencapai kinerja (performance) yang tinggi yakni pencapaian tujuantujuan organisasi dengan menggunakan sumber daya secara efisien dan efektif, atau menempatkan kinerja organisasi sebagai hasil dari formula aktivitas bisnis (organisasi), proses bisnis (organisasi) dan praktik bisnis (organisasi) berdasarkan Abdiaziz dan Ali (2014). Ini dapat dicapai salah satunya dengan berinovasi.

Inovasi itu sendiri merupakan salah satu mekanisme suatu lembaga untuk beradaptasi dalam lingkungan yang dinamis dan berkelanjutan, melalui upaya untuk menciptakan pemikiranpemikiran baru, gagasan-gagasan baru dan menawarkan solusi yang dapat menyelesaikan persoalan secara lebih efektif dan efisien. Dengan demikian inovasi pada prinsipnya adalah upaya untuk senantiasa melakukan perbaikan-perbaikan dalam suatu sistem kelembagaan untuk mencapai level yang lebih sempurna, kondisi ini secara tidak langsung tentunya akan meningkatkan kinerja organisasi.

\section{a. Inovasi Teknologi}

Technology is the result of man's learned and acquired knowledge or his technical skills regarding how to do things well (Khalil dalam Dauda, 2000:1). Akuisisi teknologi, penggunaan dan pemeliharaan merupakan faktor penentu utama untuk bertahan hidup di semua organisasi.

Quinn (dalam Dauda, 2000:2) berpendapat "that it is incumbent on any organisation to monitor technological changes, train and motivate employees to innovate, because technology covers every aspect of all organizations". Merupakan kewajiban setiap organisasi untuk memantau perubahan teknologi, melatih dan memotivasi karyawan untuk berinovasi karena teknologi meliputi semua aspek dari 
Inovasi Organisasi Dan Kinerja Organisasi :

Studi Kasus Pada Pusat Kajian Dan Pendidikan Dan

Pelatihan Aparatur III Lembaga Administrasi Negara

Dewi Sartika

semua organisasi.

Inovasi teknologi membantu perusahaan untuk membangun keunggulan kompetitif, layanan dan proses yang lebih efektif, bisnis yang baru, dan sebagainya. Technological innovation is not time barred and budgetary constraints and cost-benefit methods may to some extents hindered the application of its strategic management effectiveness. It is difficult to calculate and justify the dollar value of time spent in any $R \& D$ project that is directed towards improved technology innovation. As technology innovation can help the company to build competitive advantage through making more competitive products and services and more effective processes, or creating completely new business, both academic researchers and managers have been paying much attention to the explanation of innovation success. (Shengbin Hao, Bo Yu; iBusiness, 2011, 3, 366-371)

Kecenderungan banyak orang untuk mendefinisikan inovasi sebagai cara baru dengan bantuan perangkat dan sistem teknologi. Salah satunya, Mary Jo Hatch dalam bukunya Organization Theory, Modern, Symbolic, and Postmodern Perspective (Fontana, 2011 : 4) mendefinisikan demikian, karakteristik yang diasosiasikan dengan periode pasca industrialisasi antara lain persaingan global, fragmentasi pasar, desentralisasi produksi, pluralisme, diversitas (lingkungan), otomatisasi dan fleksibilitas pada proses produksi bertumpu pada kecepatan dan inovasi (teknologi), dan sebagainya.

Hasil survey sejenis terkait inovasi adalah Global Innovation 1000 yang memprofilkan tiga strategi innovator yaitu need seeker, market reader, dan technology drivers. Dua tipe pertama merupakan tipikal innovator penyesuai sedangkan tipe terakhir merupakan tipikal inovator pendaya tarik yang merupakan strategi inovasi yang lebih berisiko. Need seekers mengandalkan input proaktif langsung dari konsumen serta hasil riset $\mathrm{R} \& \mathrm{D}$, sementara market readers mengutamakan perubahan inkremental dan menjadi imitator tangkas di pasar, technology drivers justru cenderung mengutamakan kecanggihan teknologi sebagai basis inovasi. (Fontana; 2011, 5).

Berdasarkan Subramanian dan Nilikanta dalam Abdiaziz dan Ali (2014), inovasi teknologi dapat didefinisikan sebagai adopsi dari ide baru dengan tujuan membangun produk atau layanan baru, dan cara baru dalam membangun proses produksi/ operasi layanan organisasi.

\section{b. Inovasi Administrasi}

Berdasarkan Subramanian dan Nilikanta dalam Abdiaziz dan Ali (2014), mereka mendefinisikan inovasi administrasi sebagai proses membangun sistem manajemen baru, program pembangunan staf/pegawai dan proses administrasi baru. Inovasi administrasi sangat berkaitan dengan bentuk organisasi yang baru atau desain organisasi yang sudah ada yang mendukung penciptaan yang lebh baik, produksi dan penyampaian produk dan jasa. Sebagai contoh invasi administratif adalah manajemen dengan tujuan atau management by objective (MBO), six-sigma process, rotasi pekerjaan, sistem insentif pegawai, dan telekomuniting, dan sebagainya. (Abdiaziz dan Ali, 2014 : 114). 


\section{c. Inovasi Strategi}

Inovasi strategi menurut (Marc

Sniukas : $2014: 8$ ) adalah perubahan cara berpikir (new mind set), berbeda fokus (different focus), dan perangkat baru (new tools). Outcomenya berupa differensiasi (differentiation) dalam bentuk pasar baru (new markets), model bisnis baru (new business models) dan peningkatan nilai (increased value), yang akan menghasilkan pertumbuhan baru (new growth). Abdiaziz dan Ali (2014) menyebutkan bahwa inovasi strategi adalah sebagai bentuk pengaturan rencana formal (setting formal plan) dan membangun strategi jangka panjang organisasi untuk mencapai tujuan dan sasaran organisasi.

\section{Bangunan Hipotesis}

Inovasi adalah adalah mekanisme suatu lembaga untuk beradaptasi dalam lingkungan yang dinamis dan berkelanjutan, melalui upaya untuk menciptakan pemikiranpemikiran baru, gagasan-gagasan baru dan menawarkan solusi yang dapat menyelesaikan persoalan secara lebih efektif dan efisien. Dengan demikian inovasi pada prinsipnya adalah upaya dialektik untuk senantiasa melakukan perbaikan-perbaikan dalam suatu sistem kelembagaan untu mencapai level yang lebih sempurna, kondisi ini secara tidak langsung tentunya akan meningkatkan kinerja organisasi.

Berdasarkan penjelasan di atas dirumuskan hipotesis sebagai berikut : $\mathrm{H}_{1}$ : Diduga variabel inovasi tekhnologi

(X1) mempunyai pengaruh signifikan terhadap kinerja organisasi PKP2A III LAN (Y).Ha :Tidak terdapat pengaruh antara inovasi tekhnologi (X1) terhadap kinerja organisasi
PKP2AIILAN(Y).

$\mathrm{H}_{2}$ : Diduga variabel inovasi administrasi (X2) mempunyai pengaruh signifikan terhadap kinerja organisasi PKP2A III LAN (Y).

Ha:Tidak terdapat pengaruh antara inovasi administrasi (X1) terhadap kinerja organisasi PKP2A II LAN (Y).

$\mathrm{H}_{3}$ :Diduga variabel inovasi strategi (X3) mempunyai pengaruh signifikan terhadap kinerja organisasi PKP2A III LAN (Y).

Ha:Tidak terdapat pengaruh antara inovasi strategi (X1) terhadap kinerja organisasi PKP2A II LAN (Y).

\section{A. METODOLOGI}

\section{Desain Riset dan Prosedur Sampling}

Penelitian ini menggunakan metode penelitian kuantitatif, data primer yang dikumpulkan menggunakan kuesioner mengenai inovasi organisasi (teknologi, administrasi dan strategi) dan kinerja organisasi. Alat pengumpulan data berupa daftar pertanyaan kepada responden yaitu pegawai PKP2A III LAN, yang digali dari beberapa literatur yang diperoleh peneliti.

Objek penelitian pada riset ini adalah Pusat Kajian dan Pendidikan dan Pelatihan III Aparatur sedangkan unit analisisnya adalah para pegawai di seluruh unit kerja. Tujuan utama studi ini adalah untuk menjelaskan hubungan antara dua variabel, dimensi inovasi organisasi, dan dimensi kinerja organisasi. Teknik penentuan responden menggunakan teknik populasi dimana setiap anggota populasi dipilih menjadi anggota 
Inovasi Organisasi Dan Kinerja Organisasi :

Studi Kasus Pada Pusat Kajian Dan Pendidikan Dan

Pelatihan Aparatur III Lembaga Administrasi Negara

Dewi Sartika

responden, yakni berjumlah 41 responden. Pengambilan sampel diharapkan dapat mencerminkan kejadian-kejadian relatif dari hubungan antar variabel bebas dengan variabel tidak bebas. Profil responden yang diukur diidentifikasi melalui kuesioner, mencakup:

- Jenis kelamin; pria dan wanita;

- Umur : 25 - 35 tahun, 36 - 45 tahun, 46 tahun ke atas;

- Status : menikah dan belum menikah;

- Latar belakang pendidikan : SMU/sederajat, Diploma, Strata 1 (S1), Strata 2 (S2), Strata 3 (S3);

- Masa kerja : 1 - 5 tahun, 6 - 10 tahun dan 11 -ke atas tahun.

\section{Pengukuran Variabel (definisi operasional)}

\section{a. Inovasi Teknologi}

Inovasi teknologi adalah variabel independen dalam penelitian ini. Berdasarkan Subramanian dan Nilikanta dalam Abdiaziz dan Ali (2014), inovasi teknologi dapat didefinisikan sebagai adopsi dari ide baru dengan tujuan membangun produk atau layanan baru, dan cara baru dalam membangun proses produksi/ operasi layanan organisasi. Dalam riset ini, dimensi inovasi teknologi memiliki beberapa indikator yaitu ; Peralatan Kerja, Perlengkapan Kerja, Otomatisasi dan Electronic Proccesing (e Government), Aplikasi Perkantoran dan Sistem Informasi Manajemen (SIM), Sistem Informasi Administrasi (Records Center), Networking Internet dan intranet (konektivitas data). Empat poin skala Likert digunakan untuk mengevaluasi implementasi proses dan prosedur baru dalam organisasi, terkait pengaruhnya terhadap kinerja organisasi.

\section{b. Inovasi Administrasi}

Inovasi administrasi adalah variabel independen dalam riset ini. Berdasarkan Subramanian dan Nilikanta dalam Abdiaziz dan Ali (2014), mereka mendefinisikan inovasi administrasi sebagai proses membangun sistem manajemen baru, program pembangunan staf/pegawai dan proses administrasi baru. Dalam riset ini, dimensi inovasi administrasi memiliki beberapa indikator yaitu ; Manajemen kearsipan (records centre), Presensi, Administrasi Kepegawaian, Analisis Jabatan dan Analisis Beban Kerja, Simplifikasi Dokumentasi dan Prosedur Pekerjaan, Rotasi; mutasi, promosi, demosi dan pemberhentian, Penataan ruang dan Fasilitas Kantor, Perencanaan dan laporan, Manajemen dan kepemimpinan. Empat poin Skala Likert digunakan untuk mengevaluasi apakah organisasi mengupayakan desain ulang pekerjaan dan sistem pekerja an, peningkat a n ketrampilan/keahlian, sistem manajemen dan insentif perubahan.

\section{c. Inovasi Strategi}

Inovasi strategi adalah variabel independen dalam riset ini. Abdiaziz dan Ali (2014) menyebutkan bahwa inovasi strategi adalah sebagai bentuk pengaturan rencana formal (setting formal plan) dan membangun strategi jangka panjang organisasi untuk mencapai tujuan dan sasaran organisasi. Dalam riset ini, dimensi inovasi strategi memiliki beberapa indikator yaitu ; Remunerasi, Program unggulan (Quick wins), Team work, Share Learning dan Budaya kerja, Family Gathering, Pola Kepemimpinan, Spiritual Supporting, Kreativitas dan Pembelajaran, Pola Karir dan Sistem Karir terbuka. 


\section{d. Kinerja Organisasi}

Kinerja organisasi adalah variabel dependen dalam riset ini. Abdiaziz dan Ali (2014) menempatkan kinerja organisasi sebagai hasil dari formula aktivitas bisnis (organisasi), proses bisnis (organisasi) dan praktik bisnis (organisasi). Empat poin Skala Likert dibangun untuk menilai tingkat atau derajat kinerja (finansial dan non finansial) organisasi. Dimensi Kinerja organisasi dalam riset ini memiliki beberapa indikator yaitu ; Kesesuaian capaian program dengan visi misi lembaga, Pencapaian program, Penyerapan anggaran, Keberhasilan pimpinan, Kapabilitas pegawai, Kinerja Team work, Akuntabilitas Kinerja, Disiplin pegawai, Kemanfaatan dan kepuasan shareholders (client/ consumers).

\section{Metode Pengujian Instrumen}

Untuk memiliki instrument penelitian yang dapat diandalkan kemampuannya harus dilakukan uji validitas dan reliabilitas terhadap alat ukurnya. Dalam menguji validitas dan reliabilitas untuk perolehan data yang representatif digunakan pendekatan sebagai berikut:

\section{a. Uji Validitas}

Instrumen yang valid berarti alat ukur yang digunakan untuk mendapatkan data (mengukur) itu valid. Valid berarti instrument tersebut dapat digunakan untuk mengukur apa yang seharusnya diukur (Sugiyono : 2006; 137). Dengan kata lain, uji validitas dilakukan untuk mengetahui apakah suatu instrument alat ukur telah menjalankan fungsi ukurnya. Untuk mengetahui konsistensi dan akurasi data yang dikumpulkan dari penggunaan instrument dilakukan uji validitas dengan menggunakan analisis faktor yaitu mengkorelasikan jumlah skor faktor dengan skor total. Bila korelasi tiap faktor tersebut positif dan besarnya 0.3 ke atas maka faktor merupakan konstruk yang kuat (Sugiyono : 2006; 142). Jadi apabila korelasi antara butir-butir dengan skor total kurang dari 0,3 maka butir dalam instrument tersebut dinyatakan tidak valid. Uji validitas dalam penelitian ini dilakukan dengan bantuan program SPSS for Windows release 21.0

\section{b. Uji Reliabilitas}

Instrumen yang reliabel adalah instrumen yang bila digunakan beberapa kali untuk mengukur obyek yang sama, akan menghasilkan data yang sama (Sugiyono, 2006, 137). Reliabilitas instrumen merupakan syarat untuk pengujian validitas instrumen. Untuk mengetahui reliabilitas instrument dapat diuji dengan menganalisis konsistensi butirbutir yang ada pada instrument dengan menggunakan teknik tertentu. Pada penelitian ini uji reliabilitas dilakukan dengan menggunakan pendekatan internal consistency realibilility yang menggunakan Cronbach Alpha untuk mengeidentifikasikan seberapa baik item-item (butir-butir pertanyaan) dalam kuesioner berhubungan satu dengan yang lainnya. Sebuah faktor dinyatakan reliabel / handal jika koefisien Alpha lebih besar dari 0.6 Sebagaimana uji validitas, uji reliabilitas dalam penelitian ini juga dilakukan dengan bantuan program SPSS for Windows release 21.0

\section{Teknik Analisis Data}

Untuk menganalisis data dan menguji hipotesis, penelitian ini menggunakan analisis korelasi/ regresi dengan perangkat statistik secara umum yaitu Statistical Package for Social Science 
Inovasi Organisasi Dan Kinerja Organisasi :

Studi Kasus Pada Pusat Kajian Dan Pendidikan Dan

Pelatihan Aparatur III Lembaga Administrasi Negara

Dewi Sartika

(SPSS) for Windows Release 21.0 dengan instrumen pengujian sebagai berikut:

\section{a. Uji Koefisien Korelasi (Pearson Product Moment)}

Uji korelasi $\left(\mathrm{R}^{2}\right)$ dilakukan untuk mengetahui apakah ada hubungan antara variabel independen (X) terhadap vaiabel dependen (Y), dimana dihitung dengan analisis regresi berganda, pada intinya mengukur seberapa jauh kemampuan model dalam menerangkan variasi variabel dependen. Nilai koefisien determinasi adalah antara nol dan satu. Nilai $\mathrm{R}^{2}$ yang kecil berarti kemampuan variabel-variabel independen dalam menjelaskan variasi variabel dependen amat terbatas. Nilai yang mendekati satu berarti variabel-variabel independen memberikan hampir semua informasi yang dibutuhkan untuk memprediksi variasi variabel dependen.

Kelemahan mendasar penggunaan koefisien determinasi adalah bias terhadap jumlah variabel independen yang dimasukkan kedalam model. Setiap tambahan satu variabel independen, maka R2 pasti meningkat tidak peduli apakah variabel tersebut berpengaruh secara signifikan terhadap variabel dependen. Oleh karena itu, banyak peneliti menganjurkan untuk menggunakan nilai Adjusted $\mathrm{R}^{2}$ pada saat mengevaluasi mana model regresi terbaik. Tidak seperti R2, nilai Adjusted $\mathrm{R}^{2}$ dapat naik atau turun apabila satu variabel independen ditambahkan kedalam model.

\section{b. Uji Signifikansi Parsial (Uji t) dan Multikolinearitas}

Uji signifikansi parsial (uji t) merupakan pengujian untuk mengetahui pengaruh secara parsial variabel independen terhadap variabel dependen, serta untuk mengetahui variabel manakah yang paling dominan. Uji $t$ dilakukan dengan melihat nilai signifikansi $t$ masingmasing variabel pada output hasil regresi menggunakan SPSS dengan significance level 0,05 $(\alpha=5 \%)$. Jika nilai signifikansi lebih besar dari $\alpha$ maka hipotesis ditolak (koefisien regresi tidak signifikan), yang berarti secara individual variabel independen tidak mempunyai pengaruh yang signifikan terhadap variabel dependen. Jika nilai signifikansi lebih kecil dari $\alpha$ maka hipotesis diterima (koefisien regresi signifikan), berarti secara individual variabel independen mempunyai pengaruh yang signifikan terhadap variabel dependen.

Sedangkan uji multikolinearitas dilakukan untuk mendeteksi ada tidaknya multikolinearitas, dengan menggunakan Variance Inflation Factor (VIF). Apabila VIF $<10$, maka persamaan regresi tidak terkena multikolinearitas.

\section{c. Uji Signifikansi simultan (Uji F)}

Uji F merupaka suatu pengujian yang digunakan untuk mengetahui pengaruh secara bersama-sama (simultan) dari variabel independen tarhadap variabel dependen. Uji $F$ dapat dilakukan dengan melihat nilai signifikansi $\mathrm{F}$ pada output hasil regresi menggunakan SPSS dengan significance level 0,05 ( $\alpha$ $=5 \%)$. Jika nilai signifikansi lebih besar dari $\alpha$ maka hipotesis ditolak, yang berarti model regresi tidak fit. Jika nilai signifikan lebih kecil dari $\alpha$ maka hipotesis diterima, yang berarti bahwa model regresifit.

\section{B. HASIL DATA DAN ANALISIS 1. Profil Responden}

Dari total 41 kuesioner yang 
didistribusikan kepada responden, terdapat 39 kuesioner yang dikembalikan atau sekitar $95 \%$ dari jumlah pegawai. Seperti yang ditunjukkan tabel 4, partisipan wanita lebih dominan dalam instansi yang diteliti, dimana sekitar kurang lebih $62 \%$ merupakan responden wanita,

Tabel 4.

Karakteristik Responden

\begin{tabular}{|l|l|c|c|}
\hline \multicolumn{1}{|c|}{ Karakteristik } & \multicolumn{1}{|c|}{ Klasifikasi } & Frekuensi & Persentase \\
\hline \multirow{4}{*}{ Uenis Kelamin } & Pria & 15 & 38.46 \\
\cline { 2 - 4 } & Wanita & 24 & 61.54 \\
\hline \multirow{5}{*}{ Status Marital } & $25-35$ & 31 & 79.48 \\
\cline { 2 - 4 } & $36-45$ & 7 & 17.95 \\
\cline { 2 - 4 } & $46-k e$ atas & 1 & 2.56 \\
\hline \multirow{5}{*}{ Latar belakang Pendidikan } & Belum Menikah & 9 & 23.08 \\
\cline { 2 - 4 } & Menikah & 30 & 76.92 \\
\cline { 2 - 4 } & SMU / sederajat & 1 & 2.56 \\
\cline { 2 - 4 } & Diploma & 3 & 7.69 \\
\cline { 2 - 4 } & Strata 1 (S1) & 22 & 56.41 \\
\cline { 2 - 4 } & Strata 2 (S2) & 0 & 33.34 \\
\cline { 2 - 4 } & Strata 3 (S3) & 11 & 0 \\
\hline Pengalaman Kerja & $1-5$ tahun & 27 & 28.20 \\
\cline { 2 - 4 } & 6-10 tahun & 1 & 2.57 \\
\cline { 2 - 4 } & 11 -di atas tahun & & 69.23 \\
\hline
\end{tabular}

Sumber : Data diolah

sementara responden pria sebanyak $38 \%$. Dari status pernikahan, terlihat bahwa mayoritas responden $(76.92 \%)$ sudah menikah dan hanya $23.08 \%$ saja yang belum menikah. Secara lengkap profil responden tersaji dalam tabel berikut:

Tabel 5.

Uji Reliabilitas

\begin{tabular}{|l|c|c|}
\hline \multicolumn{1}{|c|}{ Variabel } & No. Items & Cronbach Alpha \\
\hline Inovasi Teknologi & 7 dan 12 & 0,863 \\
\hline Inovasi Administrasi & - & 0,879 \\
\hline Inovasi Strategi & 5 & 0,834 \\
\hline Kinerja Organisasi & 8 & 0,862 \\
\hline
\end{tabular}

Sumber : Data olahan SPSS 
Inovasi Organisasi Dan Kinerja Organisasi

Studi Kasus Pada Pusat Kajian Dan Pendidikan Dan

Pelatihan Aparatur III Lembaga Administrasi Negara

Dewi Sartika

Berdasarkan latar belakang pendidikan, sarjana strata 1 (S1) adalah mayoritas $(56.41 \%)$, sarjana strata dua (S2) 33.34\%, diploma 7.69\% dan SMU/ sederajat $2.56 \%$. Jika ditinjau dari masa kerja, sebanyak $28.20 \%$ dari responden mempunyai pengalaman kerja dari 1-5 tahun, $69.23 \%$ mempunyai pengalaman kerja 6-10 tahun sementara $2.57 \%$ sisanya mempunyai pengalaman kerja diatas 11 tahun, sehingga dapat dikatakan bahwa responden ini memiliki tingkat pendidikan dan lama kerja yang relatif baik dalam mengindikasikan tingkat interaksi dan pemahaman terhadap pekerjaan dan inovasi yang diterapkan di dalam tubuh organisasi.

\section{Uji Validitas dan Reliabilitas Instrumen}

Mengacu pada hasil uji validitas dan reliabilitas, skor Cronbach Alpha untuk seluruh variabel terbesar adalah lebih besar dari 0.70. Alpha tertinggi diperoleh dari kinerja organisasi $(\alpha=$ 0.862 ), inovasi administrasi adalah sesudahnya variabel menunjukkan $(\alpha=$ $0.879)$, inovasi teknologi $(\alpha=0.863)$ dan inovasi strategi ( $\alpha=0.834)$ menjadi nilai alpha terendah diantara variabel.

Selanjutnya hasil uji instrumen menunjukkan bahwa dari 39 (tiga puluh sembilan) data responden, terdapat 3 (tiga) data responden yang dikeluarkan (excluded), dan hanya 36 (tiga puluh enam) diantaranya yang layak untuk dilanjutkan untuk dianalisis.

\section{Statistik Deskriptif dan Analisis Korelasi}

Statistik deskriptif digunakan untuk melihat berbagai nilai yang mungkin, rata-rata variabel, dan standar deviasi (simpangan baku) tiap variabel. Berdasarkan hasil analisis statistik deskriptif menunjukkan bahwa nila i kinerja organisasi (Mean=38.6111, $\mathrm{SD}=5.10058)$, dilanjutkan dengan nilai inovasi teknologi (Mean=41.5556, $\mathrm{SD}=5.52627)$, dan inovasi administrasi (Mean=24.6944, SD=4.13224), serta yang terakhir adalah item inovasi strategi (M ean $=25.2222$, $\mathrm{SD}=4.01505)$, dengan jumlah data sebesar $(\mathrm{N}=36)$.

Korelasi Pearson (Product Moment) dilakukan untuk menguji hubungan timbal balik antara inovasi organisasi dan kinerja organisasi secara mandiri. Seperti yang ditunjukkan pada Tabel 7, variabel dependen dalam studi ini yaitu kinerja organisasi adalah sangat dan secara positif berkorelasi dengan tiga variabel independen, yaitu inovasi teknologi $(\mathrm{r}=0.756, \mathrm{p}=0.000)$, inovasi administrasi $(\mathrm{r}=0.818$, $\mathrm{p}=0.000)$ dan inovasi strategi $(\mathrm{r}=0.807$, $\mathrm{p}=0.000)$. Selain itu, ada korelasi yang signifikan antara variabel independen. Misalnya, inovasi teknologi secara substansial dan sangat berkorelasi dengan inovasi administrasi (0.649, $\mathrm{p}=0.000)$, dengan inovasi strategi $(\mathrm{r}=$ $0.619, \mathrm{p}=0,000)$ dan inovasi administrasi terhadap strategi $(\mathrm{r}=0.839$, $\mathrm{p}=0,000)$. Sebagaimana terlihat dalam tabel berikut : 
Tabel 6.

Nilai Korelasi Pearson (Product Moment)

\begin{tabular}{|ll|r|r|r|r|}
\hline & & Correlations \\
\hline \multirow{2}{*}{ Pearson Correlation } & KINERJA & TEKNO & ADMIN & STRATEGI \\
& KINERJA & 1.000 & .756 & .818 & .807 \\
& TEKNO & .756 & 1.000 & .649 & .619 \\
& ADMIN & .818 & .649 & 1.000 & .839 \\
& STRATEGI & .807 & .619 & .839 & 1.000 \\
\hline Sig. (1-tailed) & KINERJA &. & .000 & .000 & .000 \\
& TEKNO & .000 &. & .000 & .000 \\
& ADMIN & .000 & .000 &. & .000 \\
& STRATEGI & .000 & .000 & .000 & \\
\hline $\mathrm{N}$ & KINERJA & 36 & 36 & 36 & 36 \\
& TEKNO & 36 & 36 & 36 & 36 \\
& ADMIN & 36 & 36 & 36 & 36 \\
& STRATEGI & 36 & 36 & 36 & 36 \\
\hline
\end{tabular}

Sumber : data olahan SPSS

\section{Uji Hipotesis}

\section{a. Koefisien Korelasi $\left(\mathbf{R}\right.$ dan $\mathbf{R}^{2}$ )}

Berdasarkan hasil pengolahan data regresi dengan menggunakan SPSS, diperoleh hasil bahwa tiga variabel independen (inovasi teknologi, inovasi administrasi, inovasi strategi) secara kumulatif berpengaruh signifikan terhadap variabel dependen (kinerja organisasi) dengan nilai $\mathrm{R}=$ 0.886 , Rsquare $=0.786$ dan adjusted Rsquare $=0.776$, hal ini bermakna bahwa variabel independen mampu menjelaskan variabel dependen dengan hubungan yang cukup erat $(78,6 \%)$, sebagaimana terlihat dalam tabel 7 berikut:

Tabel 7.

Model Regresi

Model Summary

\begin{tabular}{|l|r|r|r|r|}
\hline Model & $\mathrm{R}$ & $\mathrm{R}$ Square & \multicolumn{1}{|c|}{$\begin{array}{c}\text { Adjusted R } \\
\text { Square }\end{array}$} & $\begin{array}{c}\text { Std. Error of the } \\
\text { Estimate }\end{array}$ \\
\hline 1 & $.886^{\mathrm{a}}$ & .786 & .766 & 2.46865 \\
\hline
\end{tabular}

a. Predictors: (Constant), STRATEGI, TEKNO, ADMIN

Sumber : data olahan SPSS 
Inovasi Organisasi Dan Kinerja Organisasi

Studi Kasus Pada Pusat Kajian Dan Pendidikan Dan

Pelatihan Aparatur III Lembaga Administrasi Negara

Dewi Sartika

Tabel 8.

Nilai Koefisien, Uji t dan Multikolinearitas

Coefficients

\begin{tabular}{|c|c|c|c|c|c|c|c|}
\hline \multirow[t]{2}{*}{ Model } & \multicolumn{2}{|c|}{$\begin{array}{l}\text { Unstandardized } \\
\text { Coefficients }\end{array}$} & \multirow{2}{*}{$\begin{array}{c}\begin{array}{c}\text { Standardized } \\
\text { Coefficients }\end{array} \\
\text { Beta }\end{array}$} & \multirow[b]{2}{*}{$\mathrm{t}$} & \multirow[b]{2}{*}{ Sig. } & \multicolumn{2}{|c|}{$\begin{array}{l}\text { Collinearity } \\
\text { Statistics }\end{array}$} \\
\hline & $\mathrm{B}$ & Std. Error & & & & Tolerance & VIF \\
\hline (Constant) & 5.161 & 3.281 & & 1.573 & .126 & & \\
\hline TEKNO & .321 & .101 & .348 & 3.179 & .003 & .560 & 1.786 \\
\hline ADMIN & .402 & .195 & .326 & 2.060 & .048 & .268 & 3.732 \\
\hline STRATEGI & .404 & .194 & .318 & 2.080 & .046 & .286 & 3.497 \\
\hline
\end{tabular}

a. Dependent Variable: KINERJA

Sumber : data olahan SPSS

\section{a. Uji t dan Multikolinearitas}

Adapun koefisien regresi mengindikasikan bahwa di antara variabel independen, inovasi tekhnologi mempunyai pengaruh yang paling penting terhadap kinerja organisasi $(\beta=0.348)$, diikuti inovasi administrasi $(\beta=0.326)$ kemudian inovasi strategi $(\beta=0.318)$, dengan nilai signifikansi probabilitas $<0.05$ untuk semua variabel, dengan demikian variabel inovasi terbukti signifikan mempengaruhi variabel kinerja, sebagaimana tersaji dalam tabel berikut:

Berdasarkan tabel diatas juga dapat dijelaskan apakah antar variabel terdapat multikolinearitas, dengan melihat nilai Variance Inflation Factor $(V I F)$, dimana hasil tabel menunjukkan bahwa nilai VIF berkisar antara 1 sampai 3, hal ini mengindikasikan bahwa tidak terjadi multikolinearitas antar variabel independen. (Rosari, $2006: 115$ )

\section{a. Uji Signifikansi Simultan (Uji F)}

Uji asumsi klasik selanjutnya adalah dengan melakukan uji $\mathrm{F}$, hal ini dilakukan untuk mengetahui apakah model regresi memiliki hubungan yang linier secara simultan. Berdasarkan hasil uji $\mathrm{F}$ diperoleh nilai $\mathrm{F}$ sebesar 39.138 dengan probabilitas signifikansi sebesar 0,000. $<0,05$, dengan demikian dapat disimpulkan bahwa seluruh variabel independen (inovasi) memiliki hubungan yang linier secara bersama-sama terhadap variabel dependen (kinerja). sebagaimana tersaji dalam tabel berikut

Tabel 9. Hasil Uji F (Anova) ANOVA $^{\text {b }}$

\begin{tabular}{|ll|r|r|r|r|r|}
\hline \multicolumn{1}{|l|}{ Model } & Sum of Squares & df & Mean Square & F & Sig. \\
\hline 1 & Regression & 715.541 & 3 & 238.514 & 39.138 & $.000^{\mathrm{a}}$ \\
& Residual & 195.015 & 32 & 6.094 & & \\
& Total & 910.556 & 35 & & & \\
\hline
\end{tabular}

a. Predictors: (Constant), STRATEGI, TEKNO, ADMIN

b. Dependent Variable: KINERJA

Sumber : data olahan SPSS 


\section{Pembahasan}

Berdasarkan hasil pengujian diatas dapat terlihat bahwa bahwa semua hipotesis $\left(\mathrm{H}_{1}, \mathrm{H}_{2}\right.$, dan $\left.\mathrm{H}_{3}\right)$ dapat diterima, dan hipotesis alternatif (Ha) ditolak. Diterimanya hipotesis 1 menunjukkan bahwa terdapat pengaruh positif dan signifikan inovasi teknologi dengan kinerja organisasi, dengan demikian tinggi rendahnya kinerja organisasi sangat dipengaruhi oleh inovasi teknologi. Jika melihat hasil kuesioner secara deskriptif, dapat terlihat bahwa penerapan teknologi informasi dan jaringan, baik secara online maupun offline dalam lingkungan kerja PKP2A III LAN menjadi faktor utama dalam menjelaskan kuatnya pengaruh dimensi inovasi tekhnologi terhadap kinerja, disamping itu keberadaan sistem informasi, peralatan kerja dan perlengkapan kantor yang baik tentunya dapat menunjang kinerja organisasi menjadi lebih baik.

Kesimpulan ini sejalan dengan Shengbin Hao (2011), bahwa inovasi teknologi dapat menjadi keunggulan kompetitif sehingga layanan dan proses yang lebih efektif, membangun bisnis baru dan sebagainya yang bermuara pada peningkatan kinerja organisasi. Selanjutnya dalam penelitiannya, Abdiaziz dan Ali (2014) menyatakan inovasi teknologi dapat membangun produk atau layanan baru, dan cara baru dalam membangun proses produksi/ operasi layanan organisasi sehingga mendorong pada kinerja organisasi.

Hipotesis ke 2 menyatakan bahwa semakin tinggi inovasi administrasi semakin tinggi kinerja organisasi. Dari hipotesis ini dapat disimpulkan bahwa inovasi administrasi berpengaruh positif dan signifikan terhadap kinerja organisasi. Walaupun Indikator Manajemen kearsipan, manajemen kepemimpinan dan presensi menjadi faktor yang dianggap belum berkontribusi positif terhadap inovasi administrasi, dimana sebagian besar responden menilai faktor tersebut masih cukup rendah. Hal ini tampaknya yang menjadikan pengaruh inovasi administrasi terhadap kinerja masih perlu ditingkatkan. Sementara faktor Administrasi Kepegawaian, Analisis Jabatan dan Analisis Beban Kerja, Simplifikasi Dokumentasi dan Prosedur Pekerjaan, Rotasi; mutasi, promosi, demosi dan pemberhentian, Penataan ruang dan Fasilitas Kantor, Perencanaan dan laporan menjadi faktor utama yang mempengaruhi signifikansi inovasi administrasi terhadap kinerja.

Kesimpulan ini sejalan dengan pendapat Subramanian dan Nilikanta dalam Abdiaziz dan Ali (2014) bahwa inovasi administrasi sebagai proses membangun sistem manajemen baru, program pembangunan staf/pegawai dan proses administrasi baru, membawa pengaruh positif terhadap kinerja organisasi.

Hipotesis ke 3 menyatakan bahwa semakin tinggi inovasi strategi mempunyai pengaruh signifikan terhadap kinerja organisasi, hal ini berarti bahwa inovasi strategi memainkan peran penting terhadap kinerja organisasi. Dalam indikator inovasi strategi, faktor Remunerasi, Program unggulan (Quick wins), Spiritual Supporting, Kreativitas dan Pembelajaran, Pola Karir dan Sistem Karir terbuka dianggap sebagai faktor yang paling tinggi mempengaruhi 
Inovasi Organisasi Dan Kinerja Organisasi :

Studi Kasus Pada Pusat Kajian Dan Pendidikan Dan

Pelatihan Aparatur III Lembaga Administrasi Negara

Dewi Sartika

kinerja, sementara indikator Team work, Share Learning dan Budaya kerja, Family Gathering, serta Pola Kepemimpinan dianggap menjadi faktor yang masih perlu ditingkatkan kualitasnya.

Sejalan dengan pendapat Abdiaziz dan Ali (2014) dalam penelitiannya bahwa pembangunan strategi jangka panjang organisasi untuk mencapai tujuan dan sasaran organisasi dalam bentuk inovasi strategi berpengaruh signifikan terhadap peningkatan kinerja organisasi.

\section{F. KESIMPULAN}

Tujuan utama studi ini adalah untuk meneliti hubungan antara inovasi organisasi dan kinerja organisasi pada PKP2A III LAN di Samarinda, data yang berhasil dikumpulkan sebanyak 39 responden dari 41 pegawai di PKP2A III LAN Samarinda pada Nopember 2014. Studi ini dibangun dari tiga hipotesis untuk menguji pengaruh dari dimensi inovasi terhadap kinerja organisasi.

Seperti yang telah diuraikan dalam pembahasan, diketahui bahwa terdapat pengaruh antara dimensi inovasi organisasi (tekhnologi, administrasi dan strategi) terhadap kinerja organisasi, dimana dimensi inovasi secara kumulatif berkontribusi sebesar 78,6\% terhadap kinerja organisasi. Dari seluruh variabel menunjukkan bahwa faktor inovasi tekhnologi mempunyai pengaruh yang paling penting terhadap kinerja organisasi $(\beta=0.348)$, diikuti inovasi administrasi $(\beta=0.326)$ kemudian inovasi strategi $(\beta=0.318)$.

$\mathrm{H}$ a s i l s t u d i i n i mengkonfirmasikan bahwa terdapat hubungan positif dan signifikan antara inovasi organisasi dan kinerja organisasi sehingga tiga hipotesis pada studi ini diterima, Temuan ini secara konsisten dengan penelitian sebelumnya (Mohamed Abdiaziz Sidow dan Ali Yassin Sheikh Ali, 2014).

Hasil kajian ini juga mempunyai beberapa implikasi bagi para pimpinan dan manajer publik. Kehadiran berbagai produk reformasi perundangundangan memberikan ketegasan bagi pelayanan publik pada umumnya dan organisasi yang menjalankan fungsi pemerintahan pada khususnya untuk meningkatkan inovasi dalam tubuh organisasi guna melecut kinerja organisasi, baik itu inovasi strategi dan inovasi teknologi sebagaimana tipe inovasi yang ditemukan menjadi instrument penting untuk mencapai kinerja organisasi yang berkelanjutan.

\section{Referensi}

Daft , Richard L., (2010). Era Baru Manajemen, New Era of Management, Edisi 9 Buku 1, Penerbit Salemba Empat dan CENGAGE Learning. Jakarta.

Darto, Mariman. (2011). Integrasi Sistem Perencanaan, Penganggaran dan Manajemen Kinerja : Sebuah Best Practice di Bank Indonesia, Volume 7 Nomor 2 Halaman 325-352. Samarinda.

Dauda, Dr. Yunus Adeleke, Technological Innovation and Organizational Performance: Employee Relations Strategies, Department of Industrial Relations and Public Administration Lagos State 
Inovasi Organisasi Dan Kinerja Organisasi : Studi Kasus Pada Pusat Kajian Dan Pendidikan Dan Pelatihan Aparatur III Lembaga Administrasi Negara

University, Lagos, Nigeria. Diunduh tanggal 24 Oktober 2014

doi:10.4236/ib.2011.34049 Copyright (C) 2011 SciRes. IB. Diunduh tanggal 24 Oktober 2014

Fontana, Avanti. (2011). Innovate We Can! Manajemen Inovasi dan Penciptaan Nilai Individu, Organisasi dan Masyarakat, Edisi Revisi, Cipta Inovasi Sejahtera, Jakarta.

Galbraith, J (1973). Designing Complex Organization, London: Workinham

Hao, Shengbin, Bo Yu, The Impact of Technology Selection on Innovation Success and Organizational Performance, iBusiness, 2011, 3, 366-371, Published Online December $\begin{array}{llll}2 & 0 & 1 & 1\end{array}$ (http://www.SciRP.org/journal /ib). Diunduh tanggal 24 Oktober 2014

http://www.samarinda.lan.go.id/jba/in dex.php/jba/article/view/66/78 , diunduh tanggal 06 Januari 2014

Hutauruk, Thomas R, (2010). Tinjauan Daya Inovasi Pemerintah Daerah dalam Pelaksanaan Desentralisasi di Kabupaten/ Kota Propinsi kalimantan Timur. Jurnal Borneo Administrator. PKP2A III LAN. Vol 6. No. 2(2161-2174)

Khalil, T. (2000). Management of Technology. The Key to Competitiveness and Wealth Creation, McGraw Hill;

Kusumo, A.R. (2006). Analisis Faktorfaktor yang Mempengaruhi Inovasi Produk untuk Meningkatkan Keunggulan
Bersaing dan Kinerja Pemasaran (Studi pada Industri Batik Skala Besar dan Sedang di Pekalongan). Thesis. Semarang. Universitas Diponegoro.

Lembaga Administrasi Negara RI, Bunga Rampai Administrasi Publik : Reformasi Birokrasi di Indonesia : Harapan yang Tak Kunjung Bergulir, September 2005, Jakarta.

Lukas. B \& Ferrel, O. (2000). The Effect of Market Orientation on Product Innovation. Journal of Academy of Marketing Science, 28 (2) :239-247.

Mahsun, Mohamad. (2006). Pengukuran Kinerja Sektor Publik, Edisi Pertama, Cetakan Pertama, BPFE. Yogyakarta .

Quin J.B. (1969). Technological Innovation by Multi-National Companies, USA, Harvard Business Review. Nov-Dec.

Rosari, Renati Winong. (ed). (2006). 10 Model Penelitian dan Pengolahan dengan SPSS 14. ANDI. Yogyakarta. Wibisono, D a r m a w a n. ( $\left.\begin{array}{llll}2 & 0 & 0 & 6\end{array}\right)$. Manajemen Kinerja, Konsep, Desain, d an Teknik Meningkatkan Daya Saing Perusahaan, Erlangga, Jakarta.

Schiemann. William. A. (2011). Alignment, Capability, Engagement, Pendekatan Baru Talent Management untuk mendongkrak Kinerja Organisasi, Cetakan Pertama (Bahasa Indonesia). PPM. Jakarta

Siagian, Sondang P., (2007). Teori Pengembangan Organisasi. PT Bumi Aksara, Cetakan Kelima. 
Inovasi Organisasi Dan Kinerja Organisasi

Studi Kasus Pada Pusat Kajian Dan Pendidikan Dan

Pelatihan Aparatur III Lembaga Administrasi Negara

Dewi Sartika

Jakarta.

Sidow, Mohamed Abdiaziz dan Ali, Ali

Yassin Sheikh. (2014).

Corporate Innovation and

Organizational Performance :

The Case of Somalia

Telecommunication Industry,

International Journal of

Business, Economics and Law,

Volume 4, Issue 1 (June)

Sniukas, Marc, partner at Doujak

Corporate Development,

Strategic Innovation, a

p r e s e n t a t i o n b y

marc@sniukas.com,

ww w.sniukas .com,

www.sevenprophets.com.

Diunduh tanggal 20 Oktober 2014.
Sugiyono (2006). Metode Penelitian Administrasi, Penerbit Alfabeta, Cetakan ke 14. Bandung.

Wibisono, Darmawan. (2006). Manajemen Kinerja. Penerbit Erlangga. Jakarta

Wibowo. (2006). Manajemen Perubahan, PT Rajagrafindo Persada, Cetakan Pertama. Jakarta.

Winardi. (2010). Manajemen Perubahan (The Management of Change), Edisi Pertama Cetakan ke Empat. Jakarta.

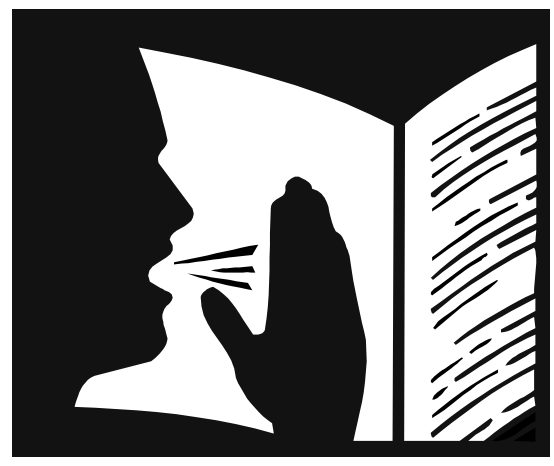

